\title{
SOME RECENT DEVELOPMENTS IN THE LAW OF LIMITATION OF ACTIONS, CONCURRENT LIABILITY AND PURE ECONOMIC LOSS
}

\author{
W.S. SCHLOSSER*
}

\begin{abstract}
Two recent decisions the Supreme Court of Canada have affirmed three important principles:

1. The running of a limitation period may be postponed until the injury is discoverable by reasonable diligence;

2. Solicitors (at least) may be concurrently liable in contract and tort, and;

3. Damage for pure economic loss is recoverable for negligent acts.

While the Supreme Court of Canada has made the law's future path clear, much remains for discussion and definition. In the short term, the practical matter of applying these decisions and predicting their effects shows there is much uncertainty yet to be resolved.
\end{abstract}

\section{INTRODUCTION}

The danger foreseen by Cardozo J. in the classic statement of the "floodgates argument" appears to come closest to realization when there is uncertainty about limitation periods, the possibility of concurrent liability and tort damages are recoverable for pure economic loss. The danger of 'liability in an indeterminate amount for an indeterminate time to an indeterminate class' reaches its greatest potential when these three elements are combined, as they often are, in a single action.

Apart from increasing the number of potential actions, uncertainty creates a danger primarily from the Defendant's point of view. He will be obliged to defend actions that could not survive formerly. But he is not the only one to suffer. The same uncertainty infects the Plaintiff's action; he may waste time and money prosecuting on the basis of a false hope.

There are other consequences as well. With uncertain time limits, some insurance risks, for example, may extend indefinately into the future. ${ }^{2}$ Other risks, such as those covered by 'claims made' policies, the type most lawyers have, will be equally indefinate and difficult to gauge owing to the possibility of claims, formerly barred, emerging from the past. In some circumstances pure economic loss may be a kind of risk not contemplated when the policy was drafted. Concurrent liability may enlarge the number of potential claimants. This may exacerbate the already great difficulties some groups have in getting insurance. As the risk becomes greater, premiums too are likely to rise.

* B.Sc. (Alberta), B.A. (King's College, Halifax), M.A. (Dalhousie), B.A. (Hon. Juris. Oxon), Associate with Duncan \& Craig in Edmonton.

1. Ultamares Corp. v. Touche (1931) 255 N.Y. 170, 174 N.E. 441,74 A.L.R. 1139 at 1145 : "If liability for negligence exists, a thoughtless slip or blunder, the failure to detect a theft or forgery beneath the cover of deceptive entries, may expose accountants to a liability in an indeterminate amount for an indeterminate time to an indeterminate class. The hazards of a business conducted on these terms are so extreme as to enkindle doubt whether a flaw may not exist in the implication of a duty that exposes to these consequences."

2. Many years later damages might be discovered which arise out of an 'accident or occurrence' covered by a long expired policy. 
Several recent decisions appear to have raised the spectre seen by Cardozo J. some 45 years ago. Central Trust Co. v. Rafuse ${ }^{3}$ and B.D.C. Limited v. Hofstrand Farms Limited ${ }^{4}$ are prominent examples. With this in mind, it is proposed that some developments in each of these areas be given a cursory look.

\section{LIMITATION OF ACTIONS}

The Central Trust case, ${ }^{3}$ a recent decision of the Supreme Court of Canada, appears to have changed the law of limitation of actions and concurrent liability. In that case, lawyers were sued by their clients for drafting a faulty mortgage. Liability was not straightforward, however. Two bold steps were required. In order to find the lawyers liable, the Supreme Court of Canada founded a principle of concurrent liability and imported a 'reasonable diligence' test into the determination of the limitation period. ${ }^{6}$

Formerly, the question of concurrent liability in contract and tort was a contentious issue with strong authority on either side. Some cases allowed it in more or less restricted circumstances; other cases found it was impossible in principle.' In most limitation statutes, reasonable diligence and the discovery of damages only mattered if there was concealed fraud. ${ }^{8}$ The Central Trust case has laid down a principle of concurrent liability and may have made the discoverability of damage universal in a limitations test. It will be useful to begin a discussion of this case with the limitation question as this aspect of the decision is likely to have the greatest practical consequences.

The case came to the Supreme Court of Canada from the Nova Scotia Court of Appeal. ${ }^{9}$ There, as in a number of provincial jurisdictions, a

3. Central Trust Co. v. Rafuse (1986) 37 C.C.L.T. 117, 31 D.L.R. (4th) 481 per LeDain J. (Dickson CJC, Beetz, Estey, McIntyre, Lamer and Wilson JJ concurring).

4. BDC Ltd. v. Hofstrand Farms Limited [1986] 3 W.W.R. 216.

5. Supra n. 3. Insofar as the Kamloops case (n. 17, infra.) can be said to represent an interpretation of the British Columbia Municipal Act, before Central Trust that decision may not have created a new rule for limitation periods. Kamloops is arguably a case about statutory interpretation. By picking up the reasoning in the Kamloops case and referring to it as a 'general rule' the test appears to have become universal. It is in this sense that Central Trust has changed the law. Cf Consumers Glass Co. v. Foundation Co. of Canada (1985) 30 B.L.R. 87 (Ont. C.A.), however.

6. Central Trust Co. v. Rafuse (1986) 37 C.C.L.T. 117 at $165-166$ and 180 . The references to this case following will be to this report unless otherwise noted.

7. The Central Trust case $i d$. contains a very thorough review of Canadian, Commonwealth and American authorities at 130-166. See also 'Solicitors Negligence: A Comment on Deyong and Raibman v. Weeks' and the cases cited there, 1984, Alberta Law Review, Vol XXII, No. 2 by the writer.

8. See, e.g. the Alberta Limitation of Actions Act, R.S.A. 1980, c. L-15, s. 6, 31 and 57. There are parallel sections in England and other provincial jurisdictions in Canada.

9. Central Trust Co. v. Rafuse (1983) 147 D.L.R. (3d) 260; dismissing the appeal from (1982) 139 D.L.R. (3d) 385. 
mortgage loan relating to the purchase of company shares is unlawful. ${ }^{10}$ Although the facts were complex, part of the loan related to the purchase of company shares. When the deal was put through, the lawyers overlooked this section of the Act.

When the mortgage came to be tested in foreclosure proceedings, it was ultimately held to be void ab initio. "The proceedings about the validity of the mortgage went all the way to the Supreme Court. The lawyers were sued in a separate action after the defect in the security was revealed. Since the relation of the mortgage loan to the share purchase was complicated, the defect was not patent and there were mixed results in both actions on the way to Ottawa.

The relevant dates in the action against the lawyers are as follows: The mortgage was taken as security for the loan December 31, 1968. A 'certificate of title' stating the mortgage formed a first charge was given by the lawyers January 17,1969 . The foreclosure proceedings were commenced April 21, 1977 and the debtor resisted the foreclosure attempts on the grounds that the mortgage was void. ${ }^{12}$

The Trial Judge upheld the mortgage in 1977 and granted an Order for foreclosure. ${ }^{13}$ In 1978 the Appellate Division found the mortgage to be unenforceable. ${ }^{14}$ The Supreme Court of Canada held the mortgage to be void ab initio, April 22, 1980.15 The Trust Company sued their lawyers in October of 1980, twelve years after the mortgage was given as security for the loan.

Since the mortgage was prepared in 1968 and about nine years elapsed before any real problems developed, a limitation defence was raised in the action against the lawyers. But it did not succeed in the Supreme Court of Canada. Giving judgment for an unanimous court and laying down what now appears to be a general principle for limitation periods, LeDain J. said: ${ }^{16}$

I am thus of the view that the judgment of the majority in Kamloops laid down a general rule that a cause of action arises for the purposes of a limitation period when the material facts on which it is based have been discovered by the Plaintiff by the exercise of reasonable diligence, and that that rule should be followed and applied to the Appellant's cause of action in tort against the Respondent's under the Nova Scotia Statute of Limitations, R.S.N.S. 1967 c 168.

10. Section $96(5)$ of the Nova Scotia Companies Act, R.S.N.S. 1967, c. 42, provides:

96(5) Subject to this section it shall not be lawful for a company to give whether directly or indirectly, and whether by means of a loan, guarantee, the provision of security or otherwise, any financial assistance for the purpose of or in connection with a purchase made or to be made by any person of any shares in the company.

See Section 42 of the Alberta Business Corporations Act, R.S.A. 198, c. B-15, for example, which is quite similar.

11. Central and Eastern Trust Company v. Irving Oil Limited and Stonehouse Motel and Restaurant Limited [1980] 2 S.C.R. 29.

12. Central Trust, supra n. 3 at $\mathbf{1 7 5 .}$

13. Central and Eastern Trust Co. v. Stonehouse Motel and Restaurant Ltd. (1977) 81 D.L.R. (3d) 495.

14. Irving Oil Ltd. v. Central and Eastern Trust Co. (1978) 89 D.L.R. (3d) 374.

15. Central and Eastern Trust Company, supra, n. 11.

16. Central Trust, supra, n. 3 at 180 (emphasis added). 
In these remarks policy considerations appear to have prevailed and instead of treating the matter simply as one of statutory interpretation, the view of limitations set out in Kamloops ${ }^{17}$ was followed. For these and other reasons, LeDain J's remarks merit close scrutiny.

Based on Section 2 (1) (e) of the Nova Scotia Limitation of Actions Act, R.S.N.S. $1967 \mathrm{c} 168$, the relevant limitation period was six years. ${ }^{18}$ If the action against the lawyers was based on contract, traditionally the clock begins to run with the breach, ${ }^{19}$ for damage is not a necessary ingredient of the cause of action. Since the faulty mortgage was prepared by the lawyers in 1968 and said to form a first charge in 1969, the Plaintiffs would have been out of time in 1974 or at the very latest, January, 1975.

Negligence, on the other hand, is actionable when all the elements of the cause of action are present; duty, breach and damage. Often the clock will begin to run when the negligence occurs. Even if the action against the lawyers was based upon tort, as it was found to be in this case, the prescription date ordinarily would have arisen in 1974 or 1975; at the same time a cause of action in contract would have expired. This is what the Court of Appeal found; the breach of duty and damage arose at the same time. Jones J.A. said:20

In this case the negligence occurred when the solicitors gave the Certificate of Title. As

found by the Supreme Court of Canada, the mortgage was void when it was delivered.

The loss at that point was the face value of the defective mortgage.

On this analysis, the action against the lawyers was long out of time unless the running of the limitation period in tort could be postponed until the damages were discoverable. The application of a broad principle such as that found in Kamloops, was used to overcome what appeared to be an insurmountable obstacle in the path of finding the lawyers liable. With respect, there may have been a way around the limitation barrier that did not require such a far reaching solution.

\section{THE REASONING LEADING UP TO THE LIMITATION PRINCIPLE}

The Court of Appeal found, and the Supreme Court of Canada affirmed, that the Plaintiff had suffered actual damage when the mortgage was drafted and said to form a first charge. We do not know precisely when default occurred, however. The reported decisions are silent about this.

17. City of Kamloops v. Nielsen (1984) 10 D.L.R. (4th) 641 (S.C.C.).

18. 2 (1) (e) All actions grounded upon any lending, or contract express or implied, without specialty, or upon any award where the submission is not by specialty, or for money levied by execution; all actions for direct injuries to real or personal property; actions for the taking away or conversion of property, goods and chattels; actions for libel, malicious prosecution and arrest, seduction, criminal conversation; and actions for all other causes which would formerly have been brought in the form of action called trespass on the case, except as herein excepted, within six years after the case of any such action arose. (emphasis added).

19. See e.g. Power v. Halley (1981) 124 D.L.R. (3d) 350 at 355-6, 17 C.C.L.T. 182 per Morgan J.A. (Nfld. C.A.).

20. Central Trust Co. v. Rafuse (1983) 147 D.L.R. (3d) 260 at 274 per Jones J.A. (Cooper and Pace JJA concurring) (N.S. C.A.). 
But it appears not to have occurred until just before April of 1977.21 In any event, problems do not appear to have developed until the spring of $1976 .^{22}$

In at least an abstract sense, the Plaintiffs had suffered damage when the lawyers said they had mortgage security and that it formed a first charge against the land. Since the mortgage was illegal and subsequently found to be void ab initio, the creditor had no in rem rights and no charge against the land right from the start. But when the loan is being repaid, albeit under a mistake of law, and if there are no intervening creditors, ${ }^{23}$ what actual damage is there?

From a technical or historical standpoint, it is well to remember we appear to be concerned with the limitation period arising out of the old action in case. Salmond and Heuston on the Law of Torts, make this general statement (emphasis added): ${ }^{23 \mathrm{~A}}$

The period of limitation begins to run at the time when the cause of action accrued, i.e. 'the earliest time at which an action could be brought'. Therefore, when a wrongful act is actionable per se without proof of actual damage, the statute runs from the time the act was committed - as in libel, assault, or interference with goods. This is so even though the resulting damage does not happen or is not discovered until a later date; for such damage is not a new cause of action but merely an incident of the old one.

When, on the other hand, the wrong is not actionable without actual damage, the period of limitation does not begin to run until that damage happens: as in the case of negligence, fraud...

Whether the wrong is described as 'negligence' or as an action based upon the old writ of case, the same idea infuses them all; there must be actual damage. This is not true of a cause of action in trespass. Salmond says: ${ }^{24}$

In case, damage is the gist of the action, and the Plaintiff will fail if he cannot prove it. But in trespass, it is not necessary to prove actual damage. Trespass is actionable per se.

What Salmond speaks of is the old direct - consequential distinction ${ }^{2 s}$ but fortunately, the evolution of the common law has made it unnecessary to apply this distinction each time. For the most part, remedies.are well established in both common law and statute.

Because most terms of a solicitor's retainer are implied and the implied terms are much like the common law duties of tort, solicitor's negligence is

21. In Central Trust id. at 264 we find: "Following default on the mortgage in April 1977, Central commenced an action for foreclosure ..." (N.S. C.A.). The Supreme Court of Canada treats April 1977 as the date the foreclosure action was started (Central Trust, supra n. 3 at 175) (S.C.C.).

22. Irving Oil became a judgment creditor in May of 1976. (Central Trust supra $n$. 13 at 496 ). Their judgment was in the order of $\$ 10,500.00$. It is submitted this interest is insignificant in light of the fact the mortgage loan in connection with the share purchase was $\$ 225,000.00$ and the damages relating to the overall loan was over $\$ 500,000.00$.

If default is not an appropriate date to start the clock running, the date another creditor intervenes might provide an alternate time to start the limitation period. On the analysis that follows in the text it is respectfully submitted either starting point puts the action against the lawyers well within time and without the need for a reasonable diligence test.

23. Seen. 22.

23A. (18th ed.) at 558-559.

24. Trespass appears to remain part of Canadian common law and exists at least conceptually in English Statute law Salmond and Heuston on The Law of Torts (18th ed) at 5-6. Bell Canada v. Cope (Sarnia) Ltd. (1980) 11 C.C.L.T. 170 at 180 per Linden J. and G.H.L. Fridman, "Trespass or Negligence?" 1971 Alberta Law Rev. IX, No. 2 at 250.

25. Salmond, id. at 5 . 
somewhat anomalous; spanning the threshold between contract and tort. Nevertheless, whether it is called breach of contract or negligence, case appears well established as an appropriate foundation for the consequential injury arising from the omissions of a professional..$^{26}$

These distinctions, while somewhat esoteric, remain important, ${ }^{27}$ not only for the emphasis on damage but for an even more fundamental distinction in the common law. Some conduct is actionable in itself, other conduct requires actual damage and proof before being actionable. Salmond further says: $:^{28}$

Just as there are cases in which damage is not actionable as a tort (damnum sine injuria), so conversely there are cases in which behaviour is actionable as a tort, although it has been the cause of no damage at all (inuria sine damno). Torts are of two kinds - namely, those which are actionable per se, and those which are actionable only on proof of actual damage resulting from them. Thus, the act of trespasssing upon another's land is actionable even though it has not done the Plaintiff the slightest harm. This is in essence the distinction between trespass and case ...

Historically, at least, professional negligence is not of the category of wrongs so repugnant it deserves sanction in itself. Rather, it falls into the class of wrongs which require the Plaintiff to prove actual injury. Actual damage is the gist of the action.

With these distinctions in mind, in circumstances where the creditor does not know of the defect, the debtor is paying, even under a mistake of law, if no third party rights intervene, and the creditor has no apparent intention of selling his security, the damages suffered from a defect in the

26. The action in case was a general remedy used for breach of a duty. Assumpsit could be used for breach of a promise. Assumpsit for misfeasance was a common remedy in actions against professionals. The remedies are similar in kind. See also Solicitors Negligence: 'A comment on DeYong and Raibman v. Weeks', supra, n. 7 at p. 295 et seq.

In this regard, a limitation for 'trespass on the case' as found in some limitation statutes need not be confusing. In Halsbury, 3rd Edition, Volume 1, pages 27-28, paragraph 50 and 51, we find:

"(50) . . . the formal part of the writ (of case) was worded similarily to that in trespass, omitting the words vi et armis. It was the remedy of Plaintiffs who sought to recover damages in cases arising either quasi ex contractu or quasi ex delicto. The former class included actions where there was a contractual relation between the parties but where the real ground of action was some breach of duty collateral to the action contract. e.g. mala praxis on the part of the surgeon ... . or (to take a modern example) an injury to a railway passenger by reason of the negligence of the company servants. The second class included actions in respect of such wrongs as public nuisances, . . . libel . . . negliglence . ....

And further:

"(51) ... actions on the case were either actions of trespass on the case, i.e. actions in respect of wrongs similar to those the subject of trespass, but unaccompanied by immediate violence; or general actions on the case, which provided a remedy for all wrongs which otherwise would have been remediless ...

The chief distinction between trespass and action on the case was that the former was brought in respect of violence either actual or implied where the matter affected was tangible and the Plaintiff's interest was immediate, while the latter was brought where the element of violence was absent or the matter affected was intangible, or the injury was consequential, or the interest was only in reversion. In actions on the case, the wrong complained of was called a tort, and not a trespass."

27. See n. 24.

28. Salmond supra, n. 24 at 13. See also McGregor, Damages (13th ed.) paragraph 293 et seq. 
security appear only to be notional. ${ }^{20}$ It is respectfully submitted that changed circumstances or further steps are required before actual damages are suffered or can be proved. Otherwise, the creditor would always have an action against his lawyers for defective security, even though the loan was paid in full.

On this basis, it appeared open to the court to find that the limitation clock did not begin to run until default or until another creditor intervened..$^{30}$ Before the mistake of law becomes known, a defect in the security has no real effect on the apparent relation of debtor and creditor. Although the date of default is not clear from the facts, problems do not appear to have developed until May of 1976 when Irving Oil became a judgment creditor. ${ }^{31}$ This would have put the client's action well within the six year limitation. With respect, such an analysis would not have required the elaborate conclusion which appears to have elevated the reasonable diligence test to a general principle.

It is respectfully submitted that a conclusion in harmony with the conceptual framework is to be preferred. But in the circumstances, it is the reasoning not the result with which one might take issue. The alternate route just mentioned would have lead to the same conclusion. The Supreme Court clearly seems disposed toward establishing the reasonable diligence principle and the facts of Central Trust gave it an excellent opportunity to do so.

Before passing to problems the decision may have created, there is one more feature of its reasoning that ought to be considered. There is no doubt a rule of law that would extinguish a litigant's claim before he knew or could discover he had one is unreasonable and unfair. But this consequence, however unfair, appears warranted in some circumstances by the limitation statutes. No doubt the legislature weighed the interest of potential Plaintiff and potential Defendant and felt compelled to draw a line; even though in some situations it might seem unfair to a potential Plaintiff. For it is equally unfair to allow an action when, owing to the passage of time, a potential Defendant has become incapable of defending himself. In this respect, limitation statutes must be somewhat arbitrary. A line must be drawn somewhere.

Most limitation statutes contain a discoverability provision in the case of concealed fraud, or suspend the running of the limitation period for parties

29. LeDain J. cites Forster v. Outred \& Co. (a firm), [1982] 2 All E.R. 753 (C.A.) in reference to the actual damage question. In that case a mortgage was placed against the Plaintiff's freehold land to secure a loan from a third party to her son. No payments were required on the mortgage unless the son defaulted. The English Court of Appeal decided the encumbrance itself gave rise to actual damage and started the clock running in negligence. The court found her action against the lawyers, whom she claimed failed to give her proper advice, to be out of time.

The question of actual damage is very carefully considered in the Forster decision. LeDain J. in Central Trust (supra, n. 3 at 177), however, indicates that doubt has been cast on one of the principal authorities cited in Forster. It is respectfully submitted that Forster is distinguishable on its facts from Central Trust. Accordingly, it is respectfully submitted that it was open to the SCC to find that actual damage did not arise until problems developed with the loan.

30. Seen. 22.

31. Supra n. 22. 
operating under a disability. ${ }^{32}$ Otherwise, the more ingenious the fraud or the more clever the crook, the more chances the wrongdoer has to get away with it. Most limitation statutes do not include similar words or provisions when they refer to other types of claim.

English courts have interpreted this to mean that the omission on the part of the legislature was deliberate and such a qualification at the reasonable diligence test cannot be read into other parts of the Act. ${ }^{33}$ Presumably, the legislature has considered the balance and has decided where it should be struck.

The English courts have considered the difference in wording in their limitation statute to present an insurmountable obstacle to importing a reasonable diligence test. In the Pirelli case, for example, Lord Scarman said: : $^{34}$

It is tempting to suggest that, in accordance with the practice statement $26 \mathrm{July,} 1966$. . the House might consider it right to depart from the decision in Cartledge v. Jopling. But the reform needed is not the substitution of a new principle or rule of law for an existing one but a detailed set of provisions to replace existing statute law. The true way forward is not by departure from precedent but by amending legislation.

Importing a reasonable diligence test was one thing, but having opened things up at that end it was their Lordship's view that one would also have to close them at the other end with a final longstop date. ${ }^{35}$ These are the 'detailed provisions' suggested by Lords Scarman and Fraser. Setting them out is far beyond the power of a court.

Our Supreme Court, however, was not constrained by 'the true way forward'. Instead they found themselves ". . . in the happy position of being free to adopt or reject Pirelli". ${ }^{36}$ And they rejected it in Kamloops. Central Trust followed Kamloops and rather than treating the matter as one of statutory interpretation or the powers of the court, appear to have extended the decision to form a general principle for limitation periods.

Canada may not have the same series of decisions and changes to statute that are seen in the events following the Cartledge decision in England ${ }^{37}$ In that respect our Supreme Court had a freer hand. But as fair as the result may be for the individual case and regardless of whether the reasoning was necessary to the outcome, the same criticisms apply. With respect, the Supreme Court of Canada has gone further than to simply interpret the Act; it has laid down a new rule. In view of the compelling suggestion that a longstop date is necessary to accompany a discoverability test, the result may not be only a case of judicial legislation; the 'new statute' may be far from complete.

32. Limitation of Actions Act, R.S.A. 1980, c. L-15, ss. 31 and 59.

33. Pirelli General Cable Works Ltd. v. Oscar Faber \& Partners [1983] 1 All E.R. 65 (HL). In Central Trust supra n. 20 (N.S. C.A.) Jones, J.A. referred to some American authorities in support of a discoverability test and said: "To adopt those cases would be tantamount to amending the statute, which this court has no power to do. Notwithstanding the extensive studies undertaken on the various Statutes of Limitation, there has been no general agreement as to the form any amendments should take ... (at 277). These remarks are acknowledged by LeDain J. in Central Trust supra n. 3 (S.C.C.) at 176

34. Pirelli id. at 72.

35. Pirelli id. at 72.

36. Kamloops supra n. 17 at 685 per Wilson J.

37. See Central Trust supra n. 3 at 178 and Pirelli supran. 33. 


\section{THE EFFECTS OF THE DECISION}

Apart from some of the questions arising from the route their Lordships decided to take, it is respectfully submitted that the result itself leaves this area of the law in a state of uncertainty. At the very least there are several points which remain for future consideration either by the courts or by the Legislature.

To begin, practitioners are left in some doubt about when limitation periods commence. The reasonable diligence test apparently suspends the running of the limitation period until the damage, objectively speaking, is discoverable. LeDain J. said ". . . the earliest it can be said the Appellant discovered or should have discovered the Respondent's negligence by the exercise of reasonable diligence was in April or May of 1977 when the validity of the mortgage was challenged in the action for foreclosure". ${ }^{38}$

In April, 1977, the foreclosure action was commenced. In about May, presumably, the defence claiming the mortgage was invalid was entered. Various results from first instance to final appeal suggest the matter was not crystal clear. With the greatest respect, it is difficult to see what potential Plaintiff might consider suing his lawyer for defective work when the basis of his suspicion is a Statement of Defence and despite the defence the lawyer's work is approved and upheld by a Trial Judge.

Actions against lawyers are sometimes commenced but held in abeyance, when a defence raises potential defects in the lawyer's earlier work. But in every case where a potential defect is raised, if the lawyer seeking to enforce the security on his client's behalf is the same lawyer that put it in place he will have to consider very carefully whether he can continue to act and whether a potential claim should be raised with the client and the Law Society. Even in the absence of an action, such considerations may well affect coverage.

If the defence is what tips off the reasonably diligent prospective Plaintiff, in jurisdictions where the limitation for tort is two years, ${ }^{39}$ it will be vital for him to consider suing his lawyer whenever a defence is entered. Moreover, he must not be lured into a false sense of security by the pronouncements of Trial Judges. ${ }^{40}$ The action can only be abandoned when appeals are exhausted or the appeal period has expired.

One may also observe that in the section of the decision dealing with the limitation defence, the court is clearly speaking about the cause of action in tort. Since the Appellant's counsel conceded that a cause of action in contract was statute barred, it was not in issue. Mr. Justice LeDain's remarks about the principle, however, appear universal; referring to '..$a$ general rule that a cause of action arises for the purposes of a limitation period . . . The general rule is then 'applied' to the cause of action in tort.

38. Central Trust supra $\mathrm{n} .3$ at $\mathbf{1 8 0}$.

39. Damages for negligent misstatement or pure economic loss may well fall under 4(1) (g) of the Alberta Limitation of Actions Act with the consequence that the limitation period is six rather than two years. It is a nice point whether for policy reasons it might be more appropriate to place it under the tort section in Part 9 of the Act giving it a two year limitation.

40. That the mortgage was upheld at first instance is perhaps the most ironic part of the decision on limitations. It places litigants in a very difficult situation. 
Since the context of these remarks is narrow and clear, it might be argued that the ratio of this aspect of the decision deals only with tort limitations and a broader principle is obiter. In this way the decision might be restricted for other situations. Given the scope of the remarks, however, the intent may well be otherwise. This too remains for future consideration.

We also do not know what the test is for reasonable diligence. Presumably, it and the test for contributory negligence are much alike. That is, in situations where a Plaintiff is contributorily negligent, application of the same kind of test may extend to providing a limitation defence. In the Central Trust case, despite the fact that some of the people at the trust company that the lawyers dealt with had legal training, no contributory negligence was found..$^{41}$ The trust company was entitled to rely upon the independent solicitors they had hired for legal advice. Since it was found that the reasonably diligent Plaintiff could not have discovered his damage until the other side entered a defence to the action for foreclosure, consideration of reasonable diligence and contributory negligence appear to have the same result. Moreover, since a potential Plaintiff may not change lawyers, he can hardly be blamed for failing to find the flaw the other side discovers and relies upon for their defence even though the client is himself a lawyer.

In any event, it is not entirely clear when the clock begins to run or what standard may be expected of the Plaintiff in discovering a cause of action. In the Central Trust case, the trust company's reliance upon their solicitors appears to be the key. This may suggest that reasonable diligence means only an absence of negligence on the part of the client and does not import any positive duty.

As mentioned above, the English courts were reluctant to bring in reasonable diligence because opening things up at this end may require closing them at the other with a final longstop date. With respect, one might speculate that the old doctrine of Laches may provide a solution to the longstop date problem without the need for legislative intervention. But the equitable doctrine of Laches is framed in the same language as that chosen by LeDain J. Although instructive, Laches is not precise. Until there is guidance on this point the running of limitation periods in Canada leaves many questions yet to be answered.

Finally, the decision may raise a difficulty peculiar to Alberta. Our Court of Appeal decided the case of Costigan v. Ruzicka ${ }^{42}$ about eight days after the decision of the Supreme Court of Canada in Kamloops was handed down. But subsequently, the Supreme Court of Canada denied the Appellant in Costigan v. Ruzicka leave to appeal. ${ }^{43}$

41. Central Trust supran. 3 at 172-174.

42. Costigan v. Ruzicka [1984] 6 W.W.R. 1, 33 Alta. L.R. (2d) 21, 31 C.C.L.T. 281, 13 D.L.R. (4th) 368, 54 A.R. 385 (Alta. C.A.).

43. [1984] 6 W.W.R. 1 XIII, 33 Alta. L.R. (2d) XXXVI. 
In Costigan, the Court of Appeal accepted the Pirelli case and rejected a due diligence test. ${ }^{44}$ In Alberta, there have been instances of Courts preferring Costigan to Kamloops. ${ }^{45}$ If limitation of actions is a procedural rather than a substantive matter and assuming that provincial Courts are masters of their own procedure, in Alberta there is some possibility the decision in Costigan may prevail even over Central Trust.

The Supreme Court of Canada in Central Trust apparently did not have the Costigan case before it. Consequently, the 'general principle' referred to by LeDain J. may not be general at all. It remains to be seen whether courts in the province are free to accept or reject this reasoning and treat the matter as one of interpretation of one of the many provincial statutes dealing with limitations. ${ }^{40}$ Such considerations may provide a way around the apparently universal statement about limitations in Central Trust.

Many aspects of the Central Trust decision on limitations have left potential litigants in a quandary. Practitioners are left in some doubt not only for their client's sake but for their own. Until several of these questions have been cleared up, a limitation defence effectively appears to have been lost. From the uncertainty about when to sue or whether an action should be maintained, there is also uncertainty about how long records should be kept and what risks are being insured.

Assuming the Central Trust case has indeed posited a general principle of limitations of actions, the Supreme Court of Canada has altered the balance originally struck by statute. At the moment, it appears to be tipped heavily in favour of potential Plaintiffs. In the short term this is likely to mean more actions. This and some uncertainties raised by the decision make the area ripe for legislative reform or at the very least, further judicial guidance. ${ }^{47}$

44. Costigan, supra n. 42 [1984] 6 W.W.R. 1 at 11-12. As Gerald Robertson points out in 'Fraudulent Concealment and the Duty to Disclose Medical Mistakes', 1987 Alta. Law Rev. Vol. XXV No. 2, p. 215 at 219, the fact that Kamloops was not considered in Costigan, strictly speaking, makes the decision per incuriam. The remarks in Costigan may also be obiter. See also n. 45 following.

45. E.g. Brent v. R. (1985) 38 Alta. L.R. (2d) 395 (Fed. Ct. T.D.) Grandwood Flooring Western Ltd. v. Prism Construction Co. Ltd. (1986) 43 Alta. L.R. (2d) 337, 69 A.R. 162 (Alta. M). In Costigan, however, the Plaintiff was long out of time on any analysis. In this light the remarks are probably obiter. At the very least, their authority is seriously impaired by the Central Trust decision. For an excellent review of the Central Trust case and the discoverability principle written just before the case went to the Supreme Court of Canada, see Rafferty, "Limitation Periods in Negligence and the Hidden Cause of Action" Canadian Business Law Journal (1987) Vol. 12, No. 3 Prof. Rafferty has since commented on the decision of the Supreme Court of Canada in "Concurrent Liability and the Running of Limitation Periods: Central Trust Co. v. Rafuse" Professional Negligence (1987) Vol. 3, No. 2, p. 52.

46. See e.g. Bera v. Marr and A-G. B.C. (1986) 27 D.L.R. (4th) 161, 1 B.C.L.R. (2d) 1; revg. (1985) 61 B.C.L.R. 195, 31 C.C.L.T. 294 and John Irvines annotation of the Central Trust case [1986] 37 C.C.L.T. 119 at 121 . One might add that parts of some limitation statutes are based upon cause; other parts are based upon effect. Perhaps this might provide a distinction as well.

47. This brings the Alberta Institute for Law Research and Reform's Report for Discussion No. 4 on Limitations into prominance. The report, written by Prof. Mapp, considers a final longstop date to be of vital importance to balance a discoverability rule. The Institute proposes an absolute cut-off time of 20 years. 


\section{CONCURRENT LIABILITY}

The second important aspect of the decision has to do with concurrent liability. Before the Central Trust decision, it was doubtful whether a solicitor could be exposed to liability in contract and tort to his client. ${ }^{48}$ There seemed little advantage to mixing 'public' duties with the private obligations of the retainer. Furthermore, the characteristics of the duty and cause of action have different potential outcomes. On the face of it, tortfeasers might plead contributory negligence as a defence while contract breakers (formerly) might not. ${ }^{99}$ The measure of damages for tort and contract are different in principle and sometimes different in practice. Limitation periods differ and the two causes of action may give rise to differing legal and factual issues and distinct evidentiary burdens.

Considerations such as these have made the courts reluctant to find concurrent liability to be possible in principle. In England, for example, the Privy Council has very recently affirmed the conservative approach. Tai Hing Cotton Ltd. v. Liu Chong Bank was a case that concerned the 'nature and extent of the duty of care owed by a customer to its bank in the operation of a current account'.$^{\circ}$ The customer and bank were in a contractual relation. Their Lordships considered whether tort liability should be imposed when the circumstances did not permit implying a term into the agreement. Lord Scarman, speaking for the unanimous Judicial Committee of the Privy Council said: ${ }^{51}$

Their Lordships do not believe that there is anything to the advantage of the law's development in searching for a liability in tort where the parties are in a contractual relationship. This is particularly so in a commercial relationship. Though it is possible as a matter of legal semantics to conduct an analysis of the rights and duties inherent in some contractual relationships including that of banker and customer either as a matter of contract law when the question will be what, if any, terms are to be implied or as a matter of tort law when the task will be to identify a duty arising from the proximity and character of the relationship between the parties, their Lordships believe it to be correct in principle and necessary for the avoidance of confusion in the law to adhere to the contractual analysis: on principle because it is a relationship in which the parties have, subject to a few exceptions, the right to determine their obligations to each other, and for the avoidance of confusion because different consequences do follow according to whether liability arises from contract or tort, eg in the limitation of action. Their Lordships respectfully agree with some wise words of Lord Radcliffe in his dissenting speech in Lister v. Romford Ice and Cold Storage Co Ltd [1957] 1 All ER 125 at 139. [1957] AC 555 at 587. After indicating that there are cases in which a duty arising out of the relationship between employer and employee could be analysed as contractual or tortious Lord Radcliffe said:

"Since, in any event, the duty in question is one which exists by imputation or implication of law and not by virtue of any express negotiation between the parties, I should be inclined to say that there is not real distinction between the two possible sources of obligation. But it is certainly, I think, as much contractual as tortious. Since, in modern

48. See e.g. "Solicitors Negligence: A Comment on DeYong and Raibman v. Weeks' supra n. 7 and the cases cited there.

49. Now see Doiron v. Caisse Populaire D'Inkerman Ltee. (1985) 17 D.L.R. (4th) 660 (S.C.C.) where a defence of contributory negligence was allowed in a contractual setting.

50. Tai Hing Cotton Ltd. v. Liu Chong Hing Bank [1985] 2 All E.R. 947 at 949 . See also J.G. Logie "The Basis of a Solicitor's Liability To His Clients: Rethinking The Rules Again" The Law Society's Gazette (Nov. 1986). The most recent Canadian decision on the relation of banker and client appears to be Canadian Pacific Hotels Ltd. v. Bank of Montreal unreported June 4, 1987, Supreme Court of Canada. The case discusses the effects of the decision on concurrent liability in Central Trust.

51. Tai Hing, id. at 957. 
times, the relationship between master and servant, between employer and employed, is inherently one of contract, it seems to me entirely correct to attribute the duties which arise from that relationship to implied contract."

Their Lordships do not, therefore, embark on an investigation whether in the relationship of banker and customer it is possible to identify tort as well as contract as a source of the obligations owed by the one to the other. Their Lordships do not, however, accept that the parties' mutual obligations in tort can be any greater than those to be found expressly or by necessary implication in their contract. If, therefore, as their Lordships have concluded, no duty wider than that recognised in Macmillan and Greenwood can be implied into the banking contract in the absence of express terms to that effect, the respondent banks cannot rely on the law of tort to provide them with greater protection than that for which they have contracted.

The Supreme Court of Canada took this decision into consideration and although they may not have reached a different result, came to a different conclusion about concurrent liability. LeDain J. said. ${ }^{52}$

"... I am of the opinion that if the Respondent's solicitors were negligent in the performance of the professional services for which they were retained, they would be liable in tort as well as contract to the Appellant ..."

Subject to the remarks made immediately before this statement, the Supreme Court of Canada does not oppose concurrent liability. Indeed they found the lawyer liable in tort where before liability arguably had been restricted to contract.

After a very thorough review of the authorities on concurrent liability, the court concluded: ${ }^{33}$

(1) The common law duty of care that is created by a relationship of sufficient proximity in accordance with the general principle affirmed by Lord Wilberforce in Anns v. Merton London Borough Counsel . . . is not confined to relationships that arise apart from contract.

(2) What is undertaken by the contract will indicate the nature of the relationship that gives rise to the common law duty of care, but the nature and scope of the duty of care that is asserted as the foundation of the tortious liability must not depend on specific obligations or duties created by the express terms of the contract ...

(3) A concurrent or alternative liability in tort will not be admitted if its effect would be to permit the Plaintiff to circumvent or escape a contractual exclusion or limitation of liability for the act or omission that would constitute the tort. Subject to this qualification, where concurrent liability in tort and contract exist, the Plaintiff has the right to assert a cause of action that appears most advantageous to him in respect of any particualr legal consequence.

The Supreme Court also concluded that solicitors should be in no different position than other professionals with respect to concurrent liability and that such concurrent liability was not restricted to professional advice; ${ }^{34}$ it applied 'to any act or omission in the performance of the services for which a solicitor has been retained'.ss

With respect, what is particularly unfortunate about bringing solicitors in line with other professionals on the concurrent liability question is that they are now in a highly anomalous position where limitations are concerned. The Alberta Limitation of Actions Act R.S.A. 1980, c. L-15,

52. Central Trust supra n. 3 at 166.

53. Central Trust supra n. 3 at 165-166. See also Morrison v. McCoy Bros. Group [1987] 3 W.W.R. 301 per Cooke J.

54. Central Trust supra n. 3 at 166.

55. Central Trust supra n. 3 at 166. 
section 55, limits the time for bringing an action against doctors and dentists, for example, to one year after the services terminated. Lawyers do not enjoy the same restrictions. If lawyers can now be sued in tort and the effect of Central Trust is to enlarge tort limitations, the time for an action against lawyers is much greater. Thus, while lawyers may no longer be in an anomalous position in one respect, the combination of Central Trust and existing statute law may put them in a highly anomalous situation in another. ${ }^{\text {ssA }}$

These conclusions bring the tortious liability of a solicitor in line with some aspects of the English common law. In Canada as well as England, a solicitor may be liable to third parties on the Hedley Byrne principle. ${ }^{36}$

Insofar as the third conclusion is concerned, the decision is consistent with the result in Tai Hing. In other words, a Plaintiff cannot rely on the law of tort to provide a greater measure of protection than that for which he has contracted. ${ }^{37}$ It is not clear, however, whether lawyers may be liable to third parties outside the Hedley Byrne principle for plain negligence.$^{58}$ If this is so, the scope of solicitor's liability is widened to include anyone in the range of proximity or foreseeability.

In this repsect, the class of potential claimants is presently uncertain and requires definition. Instead of just clients and third parties in a 'special relation', a solicitor's duties may extend to anyone within the range of 'neighbourhood'. Extending ordinary negligence to solicitors does not appear to be inconsistent with the conclusion drawn by the court in Central Trust. ${ }^{99}$ One can only speculate that the peculiar features of the adversarial system will be employed to negative or limit duties on the grounds of public policy in the mode of v. Anns v. Merton.60

What remains is a brief consideration of the differences between tort and contract that may affect the remedy. In Canada, Doiron v. La Caisse Popular D'Inkerman ${ }^{61}$ found that a defence of contributory negligence is available in a contractual setting. This was also affirmed in the Central Trust case. Such is not the case in England ${ }^{62}$ and may have been one of the things taken into account when the Privy Counsel chose a conservative

55A. See also, "Fraudulent Concealment and the Duty to Disclose Medical Mistakes" supra n. 44 at 219 et seq.

56. In England: see Midland Bank Trust Co. v. Hett, Stubbs \& Kemp [1979] Ch. 384, [1978] 3 All E.R. 571 per Oliver J.; Ross v. Caunters [1979] 3 All E.R. 580 (Ch. D) per Megarry V.C., for example.

In Canada: Wittingham v. Crease \& Co. (1978) 88 D.L.R. (3d) 353 (B.C. S.C.) per Atkins J.; Tracey \& Morin v. Atkins (1979) 16 B.C.L.R. 223 (B.C. C.A.) per Nemetz C.J.B.C.; Burman's Beauty Supplies Lid. v. Kempster (1974) 4. O.R. (2d) 626 (Co. Ct.). Whether the Plaintiff be a client or third party, Hedley Byrne \& Co. v. Heller \& Parnters Ltd. [1964] A.C. 465, [1963] 2 All E.R. 575 (H.L.) is usually cited as the basis of tort liability.

57. Central Trust supra n. 3 at 166.

58. Since the concurrent liability of solicitors is essentially put on par with ordinary negligence (Central Trust supra n. 3 at 166 ) this may well be the effect of the decision.

59. See n. 58 id.

60. Anns v. Merton London Borough Counsel [1978] A.C. 728 [1977] 2 All E.R. 492 (H.L.). See also n. 67 following.

61. Dorion supra n. 49.

62. Law Quarterly Review of "Apportionment in Professional Negligence Cases: Contributory Negligence", A.M. Dugdale, Professional Negligence, May/June 1985 at 96. 
approach to concurrent liability in Tai Hing. In this setting, then, the contributory negligence defence does not provide a factor to be considered in choosing one remedy over another.

Although in some circumstances the measure of tort and contract damages are different, for all practical purposes awards are the same. ${ }^{63}$ This too, may not provide a significant difference between the remedies.

With the extension of a limitation period in tort by the reasonable diligence test, the difference in limitation periods - two rather than six years in most circumstances ${ }^{64}$ will not affect an action. In any event, the Plaintiff is able to choose the form of action that best suits him. ${ }^{.5}$

Different legal and factual issues and differing evidentiary 'burdens', however, may create problems which remain to be solved. Since a tortious and contractual cause of action against a solicitor has the same conceptual basis, the old writ of case, the remedies are similar in kind. Morever, the implied obligations in a contract are much like the common law duties in tort ${ }^{66}$ But the modern separation and divergence of tort and contract may have left some differences that must be reconciled in the new union.

The terms and existence of an agreement are ordinarily questions of fact. Implied terms, however, like the existence of a duty in a negligence action, are questions of law and arise from decided cases and statute. ${ }^{67}$ In most cases, deciding whether the breach of an implied term or the breach of a duty gives rise to solicitor's liability involves the same steps.

Similarly, the extent of an implied obligation, like the existence of a duty, is a question of law. ${ }^{68}$ The standard of conduct required to establish a breach is itself a question of fact for which expert evidence is admissible. ${ }^{69}$

63. See, e.g. H. Parsons (Livestock) Ltd. v. Uttley Ingham \& co. (1973) 3 W.L.R. 990 (QB); Anglia T.V. v. Reed [1972] 1 Q.B. 60; Esso Petroleum Co. Ltd. v. Mardon [1976] 2 All E.R. 5 at 15 (C.A.) per Lord Denning M.R. (as he then was). In Kienzle v. Stringer (1981) 21 R.P.R. 44 at 49 et seq. Zuber J.A. found the tests of remoteness in tort and contract to be so imprecise as to be practically indistinguishable. In John Maryon Int. Ltd. v. New Brunswick Telephone Co. Ltd. (1982) 141 D.L.R. (3d) 193 at 226 (N.B. C.A.) La Forrest J.A. (as he then was) suggests that which foundation one chooses rarely will make a difference. Contra see Asamera Oil Corp. Ltd. v. Sea Oil \& General Corp. (1978) 89 D.L.R. (3d) 1 at 8 (S.C.C.) per Estey J. and The Heron II [1969] 1 A.C. 30 (H.L.) per Lord Reid, e.g.

64. Unless the damages are discoverable with reasonable diligence at the time the duty is breached. See also n. 39.

65. Central Trust supran. 3 at 166.

66. See "Solicitors Negligence: The Appeal of DeYong" (1985) Albeta Law Review Vol XXIII, No. 3 at 503 by the writer.

67. See W.L. Prosser The Law of Torts (4th ed., 1971) 205. Salmond and Heuston on the Law of Torts (18th ed.) at 183 . It now may be slightly misleading to put things this way where common law negligence is concerned. The authors of this latter source cite Arenson v. Casson, Beckman, Rutley \& Co. [1977] A.C. 1004 at 1011 and Anns v. Merton London Borough Counsel [1978] A.C. 728 at 751-752. Per Lord Wilberforce suggests that in negligence actions the emphasis has shifted from looking at cases to find a duty, to negativing a prima facie duty on public policy considerations. On the general question of implied term in contract see G.H. Treitel, The Law of Contract (6th ed., 1983) 158; Cheshire and Fifoot, Law of Contract (10th ed., 1981) 115; S.M. Waddams, The Law of Contract (2nd ed., 1984) 366. Here the starting point is usually The Moorcock [1886-90] All E.R. Rep. 530 at 534 and 535 per Bowen L.J.. It appears simpler to exclude implied terms in contract than to limit a duty in the tort of negligence.

68. See Prosser, id., e.g.

69. DeYong v. Weeks (1984) 55 A.R. 305, Leave to appeal to the S.C.C. denied Jan. 21, 1985, (1985) A.W.L.D. in February 1985, No. 233. 
It is not admissible to show the existence of a duty but course of conduct may well go to support an implied term. ${ }^{70}$

Since Anns v. Merton," however, the 'burden' of showing no duty essentially falls to the Defendant in a negligence action. ${ }^{72} \mathrm{He}$ must show policy reasons to negative or limit the duty alleged by the Plaintiff. In a contract case, the burden lies upon the Plaintiff to establish grounds for an implied term. Unlike a negligence action, an implied duty is perhaps less likely to be assumed.

These differences are not significant in practice, however, and may have little effect except on technical grounds in an appeal. Furthermore, if a tort duty will not be found when it would be excluded by the retainer, solicitors are essentially in no different position under the new regime of concurrent liability.

It remains to be seen, however, whether estoppel, the doctrine of consideration or various differences between kinds of misrepresentation will have any application. If a Plaintiff can choose whichever cause of action best suits him 'in respect of any particular legal consequence' and he chooses tort, it is not clear whether this would have the effect of precluding the Defendant's use of contractual defences, equitable defences that formerly arose only in a contractual setting, or relying upon differences in the nature of various forms of misrepresentation. ${ }^{73}$ These questions will have to be answered by subsequent decisions.

Apart from the advantages gained by giving a Plaintiff a potentially longer limitation period, it is not clear what real improvements concurrent liability has made. Aside from the possibility of widening the scope of potential claimants, ${ }^{74}$ and raising doubts about defences and differences peculiar to the tort or contract setting, the chief differences between a contract or a tort remedy in these circumstances may prove only to be a matter of legal semantics.

\section{PURE ECONOMIC LOSS}

Damages for pure economic loss are recoverable in several well established situations; breach of contract and negligent misstatement are prominent examples. ${ }^{75}$ Where a negligent act is concerned, it has been a matter of dispute whether damages for pure economic loss are recoverable

70. DeYong, id. at 316. R.N. Mahoney, "Lawyers - Negligence - Standard of Care" 63 Can. Bar Rev. 221 at 234 suggests Laskin C.J.C. (as he then was) viewed the matter differently Reibl v. Hughes [1980] 2 S.C.R. 880, (1981) 114 D.L.R. (3d) 1.

An implied term may be fact or law; Treitel, The Law of Contract (6th ed.) $160 \mathrm{et} \mathrm{seq.} \mathrm{On} \mathrm{the}$ question of course of conduct or custom see Treitel at 164-165. There are numerous Canadian and English authorities which provide examples.

71. Anns supra n. 60.

72. See n. 67.

73. In Canadian Western Natural Gas Co. v. Pathfinder Surveys Ltd. (1980) 12 Alta. L.R. (2d) 135, 12 C.C.L.T. 211, 21 A.R. 459 (Alta. C.A.). Prowse \& Harradence J.J.A. (concurring) found that one cannot by framing an action in contract deprive a defendant of a defence of contributory negligence. Concerns about losing defences may not be warranted but the question remains open. See also the Canadian Pacific Hotels case supran. 50 which indicates a conservative approach will be taken.

74. If the question of solicitors' liability has essentially become a matter for ordinary negligence.

75. For a very thorough review of this area see Feldthusen, Economic Negligence (1984). 
if they are not in some way related to physical injury. Thus, decisions which shed light on this question are bound to be of great interest. Although the subject is complex and a proper examination of it is beyond the scope of this comment, A.G. Ontario v. Fatehi ${ }^{76}$ and B.D.C. Ltd. v. Hofstrand Farms Ltd. ${ }^{n}$ provide some insight into the present state of the law.

In the first case, Fatehi's negligent driving required that money be spent to clean up the highway. The municipality did so, charged the Provincial Government and the Provincial Government, in turn, sued Fatehi to recover the cost and won.

The relation of damage to injury to property did not leave a clear set of facts on which to decide the issue of pure economic loss. ${ }^{78}$ Nevertheless, Estey J. writing for the majority said: ${ }^{\text {p9 }}$

It is not possible to say whether the law of Canada as reflected in the authorities to-date contemplates recovery for pure economic loss ..."

The next available opportunity to deal with this subject apparently arose in the Hofstrand Farms case. In that case, an agreement for sale of land depended upon registration of Crown grants by a certain date. Time was of the essence. The Department of Lands had the grants, but they were required to be registered in another city. The Clerk offered to have the grants sent by courier. Three days before the deadline the courier agreed to deliver the grants by the next day but did not deliver them until several days after the deadline. The real estate transaction failed and the vendor sued the courier.

Mr. Justice Estey (Chouinard and Lamer JJ. concurring) allowed the courier's appeal and began by affirming that the case concerned a claim in negligence for pure economic loss. In a review of the authorities his Lordship said:80

In Rivtow Marine Ltd. v. Washington Iron Works [1974] S.C.R. 1189, [1973] 6 W.W.R. 692, 40 D.L.R. (3d) 530 [B.C.], this court divided on some aspects of the issue of negligently caused economic loss, but both the majority and dissenting judgments recognized that, in principle, a Defendant could be held liable tin tort for economic losses arising wholly in the absence of associated physical injury or damage.

In short, the Supreme Court of Canada removed the many years of doubt about the effect of Rivtow and the circumstances required for the recovery of pure economic loss. In the Hofstrand Farm case, however, recovery was not permitted since there were not sufficient limits of proximity and reliance. Mr. Justice Estey concluded: ${ }^{81}$

In sum, the requirements of proximity contained in the principles ennunciated in Hedley Byrne and confirmed in Anns, supra, are not met on the facts of this appeal. As I have concluded that the Respondent did not come within a limited class in the reasonable contemplation of a person in the position of the Appellant, it is unnecessary to proceed to the second stage or test set out by Lord Wilberforce in Anns.

76. [1984] 2 S.C.R. 536, 15 D.L.R. (4th) 132, 31 C.C.L.T. 1 (S.C.C.) A very instructive comment on this case appears in 1986 Supreme Court Law Review, Vol. 8 at 365. 'A Step Backward Economic Loss: A.G. Ontario v. Fatehi'.

77. [1986] 3 W.W.R. 216 (S.C.C.). In England the most recent case concerning pure economic loss appears to be Leigh \& Sillavan Ltd. v. Aliakmon Shipping, [1985] 2 All E.R. 44 (C.A.).

78. Fatehi supra n. 76 at 542 and 545.

79. Fatehi supra n. 76 at 615.

80. Hofstrand Farms supra n. 77 at 225.

81. Hofstrand Farms supra n. 77 at 228. 
Morever, the court found that damages were, in any event, too remote. ${ }^{82}$

The Hofstrand Farms case indicated in clear language that there may be appropriate situations in which damages are recoverable for a negligent act giving rise to pure economic loss. Matters of proximity and remoteness aside, what remains for future consideration is a clear definition of the appropriate circumstances. In this regard, his Lordship continued: ${ }^{83}$

The Anns principle sets out a broad and independent right and a concommentant liability in the law of negligence. It has found application in a variety of ways and circumstances in the courts of this country and elsewhere in the years it was decided. Doubtless, the principle and its reach will be the subject of discussion in the courts as the law of torts continues to evolve . . . no doubt the courts of this country will continue to search for reasonable and workable limits to the liability of a negligent supplier of manufactured product for services, to the liability of a negligent contractor for the contractual undertakings owed to others, and to the liability of persons who negligently make misrepresentations. In this search the courts will be vigilant to protect the community from dangers suffered by a breach of the "neighbourhood duty". At the same time, however, the realities of modern life must be reflected in the ennunciation of a defined limit on liability capable of practical application, so that the social and commercial life can go on unimpeded by a burden outweighing the benefit to the community of the neighbourhood historic principal.

Thus the remedy is available but this dicta indicates the courts will exercise caution in awarding it. It remains to be seen what will be sufficiently proximate to justify recovery. In this area of the law too, judicial guidance will be of great assistance.

\section{CONCLUSION}

These two decisions, Central Trust v. Rafuse and B.D.C. v. Hofstrand Farms Ltd. lay down a clear direction for future developments in the law. Central Trust finds that a reasonable diligence test can be invoked to postpone the running of a limitation period and that concurrent remedies in contract and tort are available. The Hofstrand Farms case affirms there can be recovery for negligent acts giving rise to purely economic loss. How wide the doors have been opened to potential litigants remains for future consideration.

For each of these elements there is some similarity to the situation shortly after the decision in Donahue v. Stevenson. ${ }^{84}$ As Spencer, Bower and Turner have observed: ${ }^{85}$

In extending the area of tortious responsibility, as it should henceforth be delineated, the Lords adopted Luke X, 25-37 as stating the new principle - but with the addition of a modern gloss upon the simple admonition there recorded. For it had of course to be acknowledged at once that the duty to one's neighbours so clearly stated in the parable is not recognized by the common law as extending to all cases. But the Lords did not attempt to say, to what cases it did apply; and the courts are still involved in finding the classes of cases to which they must be deemed to have intended the duty of an Atkinian neighbour to be limited.

The course set for the courts is to define the kinds of circumstances to which each of these three developments will apply. In light of the questions these decisions raise and despite the courts admonitions about proper

82. Hofstrand Farms supra n. 77 at 228.

83. Hofstrand Farms supra n. 77 at 228.

84. Donoghue (M'Alister) v. Stevenson [1932] A.C. 562, [1932] All E.R. Rep. 1 (H.L.).

85. The Law of Actionable Misrepresentation, Spencer Bower and Turner (1974) 436 para 414. Luke X, 25-37 contains the parable of the good Samaritan. 
limits, we appear to be potentially closer to the threat seen by Cardozo J. than ever before.

Before closing, a general observation about these decisions might be in order. Perhaps ironically, in recent times the general tendency of the common law appears toward a resurrection of a much older view. Despite its sophistication and complexity, as the idea of public duties grows, less importance appears to be attached to individual intent and the ability of individuals to govern their own affairs through contract. The body of statutes and recent common law appears to emphasize status in determining liability. The Supreme Court of Canada appeared to be strongly influenced by a status argument when coming to their decision about concurrent liability in Central Trust. ${ }^{86}$

Spenser, Bower and Turner have made this observation about the path of negligence: ${ }^{87}$

The duty to take care is one which arises out of the relative situations of Plaintiff and representor. To this extent, at least, Hedley Byrne can be seen as another step in the series of cases, of which M'Alister (or Donoghue) v. Stevenson is so conspicuous an example, which illustrate the reversal, in the development of the common law in recent years, of that tendency of progressive societies noticed more than 100 years ago by Sir Henry Maine, to proceed from status to contract.

With the growth of an action in negligence and the possibility of concurrent liability, Central Trust and the Hofstrand Farms cases in Canada may well be added to the list illustrating this trend. From a jurisprudential viewpoint, modernization of the law may be bringing it full circle.

At the very least, Central Trust and Hofstrand Farms have ended a great deal of uncertainty and speculation about limitation periods, concurrent liability and pure economic loss. In this respect the decisions are to be welcomed. The path now set leaves much for future consideration and definition and since the effects of these decisions can be far reaching, new refinements in these areas are bound to be of great interest.

These decisions have set an ambitious course and presently leave much to judicial discretion. the limits appear chiefly to be defined by Cardozo J's warning about the danger of liability 'in an indeterminate amount for an indeterminate time to an indeterminate class'. It remains to be seen with what restraint this course will be followed and what adjustments will follow in its wake.

86. Central Trust supra n. 3 at 141, 142, 143.

87. The Law of Actionable Misrepresentation supra n. 85 at 432 para. 411 , citing Ancient Law, Sir Henry Maine (1861). See Ancient Law Beacon Press reprint 1970 at 164-5. There we find (at pages 163 and 165):

"Nor is it difficult to see what is the tie between man and man which replaces by degrees those forms of reciprocity in rights and duties which have their origin in the Family. It is contract. Starting, as from one terminus of history, from a condition of society in which all the relations of Persons are summed up in the relations of Family, we seem to have steadily moved towards a phase of social order in which all these relations arise from the free agreement of individuals.

... If then we employ Status, agreeably with the usage of the best writers, to signify these personal conditions only, and avoid applying the term to such conditions as are the immediate or remote result of agreement, we may say that the movement of progressive . societies has hitherto been a movement from Status to Contract."

Increasingly, the 'tie between man and man' appears to be the common law duties of tort. It is in this sense that the law now appears to be proceeding from contract back to status. 